PROCEDIA

Studi Kasus dan Intervensi Psikologi

ISSN:2302-1462

Volume 7(1) 13-24, Januari 2019

DOI: $10.22219 /$ procedia.v7i1.12977

\title{
Positive activity untuk meningkatkan kepercayaan diri pada pasien skizofrenia
}

Ulya Rahmatullatifa Umami, Universitas Muhammadiyah Malang, Malang, Indonesia

Korespondonesi:

Ulya Rahmatullatifa Umami, UniversitasMuhammadiyah Malang, Malang, ulyarahma1@gmail.com

\begin{abstract}
Riwayat artike
Naskah diterima:

07/11/2018

Revisi diterima:

01/12/2018

Naskah disetujui: $12 / 12 / 2018$
\end{abstract}

\begin{abstract}
Abstrak
Subjek memiliki kerentanan psikologis yang membuat Subjek mengalami berbagai hambatan dalam kesehariannya. Hasil asessmen menggunakan observasi, wawancara dan alat test psikologi menunjukkan bahwa Subjek terdiagnosa gangguan Skizofrenia dengan permasalahan rendahnya kepercayaan diri. Rendahnya kepercayaan diri Subjek menimbulkan hambatan dalam performa subjek. Subjek menjadi tidak produktif dalam kesehariannya karena selalu menolak untuk mengerjakan suatu tugas atau mengikuti kegiatan. Intervensi dilakukan menggunakan teknik positive activity dengan pendekatan behavior. Tujuan intervensi meningkatkan kepercayaan diri subjek. Instrumen menggunakan Self-confident Scale sebagai pretest dan posttest. Hasil intervensi menunjukkan adanya perubahan perilaku pasif Subjek mulai berkurang, intensi Subjek membicarakan mengenai kondisi fisiknya yang kurang menarik mulai berkurang dan pemahaman Subjek mengenai kepercayaan dirinya mulai bertambah.

Kata kunci: Positive activity, kepercayaan diri, skizofrenia, intervensi.
\end{abstract}

\section{Latar Belakang}

Skizofrenia merupakan gangguan mental psikotik yang menyebabkan disorganisasi fungsional yang besar sehingga gangguan ini tergolong berat dan dapat menyebabkan bunuh diri (Mcgirr \& Turecki, 2008). Individu dengan skizofrenia umumnya mengalami gangguan kepribadian, adanya waham, delusi dan distorsi pikiran mendasar yang khas (Ritsner, Ponizovsky, Timinsky, Bistrov, \& Modai, 2003). Hal tersebut dapat menghambat individu dalam aspek kognitif, afektif, sosial dan performance. Skizofrenia dapat menyebabkan berbagai permasalahan, diantaranya rendahnya kepercayaan diri individu dan menyebabkan penarikan diri, sehingga menimbulkan hambatan untuk bersosialisasi (Harvey \& Penn, 2010). Rendahnya kepercayaan diri menghambat individu untuk mengeluarkan kemampuan dan potensinya sehingga akan terjadi penghindaran ketika diberikan tugas atau mengikuti kegiatan (Sxufkdvh et al., 2014). 
Penanganan paling mendasar pada individu dengan skizofrenia menggunakan farmakologi (Rosenheck et al., 2005). Obat-obatan yang diberikan bertipe antipsikotik seperti clozapine atau risperidone (Chan et al., 2006). Pendekatan farmakologi dianggap efektif untuk penanganan dasar skizofrenia karana dapat bereaksi dengan cepat dan individu menjadi tenang kembali (Taipale, Mehtälä, Tanskanen, \& Tiihonen, 2018). Namun pemberian pendekatan farmakologi memberikan efek jangka pendek. Diperlukan penanganan dengan psikoterapi untuk memperbaiki perilaku dan keberfungsian individu sehari-hari. Terapi yang digunakan adalah positive activity untuk mendorong individu melakukan kegiatan dan percaya akan kemampuannya. Penggunaan terapi positive activity telah terbukti untuk menigkatkan well being (Lyubomirsky \& Layous, 2013). Sedangkan penggunaan positive activity untuk meningkatkan kepercayaan diri dimaksudkan agar perlahan akan membentuk keyakinan dalam diri individu bahwa dirinya mampu melakukan sesuatu.

\section{Metode Asesmen}

Sebelum melakukan asessmen dilakukan screening mengenai kondisi pasien terlebih dahulu. Screening digunakan untuk mengidentifikasi status mental dan kondisi mental subjek. Selain itu screening juga berfungsi sebagai konfirmasi mengenai adanya gejala-gejala yang ada pada diri subjek. Screening menggunakan Mini Mental State Examination (MMSE) bertujuan untuk mengidentifikasi ada tidaknya pelemahan kognitif pada diri subjek. MMSE terdapat beberapa pertanyaan sederhana diantaranya pertanyan mengenai orientasi (tempat Subjek saat itu, tanggal, hari), dan perintah sederhana seperti melipat kertas dan menaruh di lantai. Screening juga menggunakan WHODAS dimana pengisian dilakukan oleh pemeriksa dengan sumber dari observasi, wawancara dengan keluarga, pengasuh Subjek dan subjek. Penggunaan WHODAS bertujuan untuk mengidentifikasi kondisi kesehatan mental dan produktivitas Subjek dengan adanya gejala yang muncul.

Setelah dilakukan screening, kemudian dilakukan asessmen untuk diagnosa dan penentuan intervesi dilakukan dengan serangkaian metode antara lain observasi, wawancara, dan test psikologi. Test psikologi menggunakan beberapa alat test diantaranya Grafis (BAUM, DAP, HTP), WWQ, SSCT, TAT, Wartegg dan WAIS. (a) Observasi bertujuan untuk melihat perilaku Subjek meliputi kebiasaan, kesukaan, gejala yang timbul (seperti jalan tanpa arah, melamun), pola interaksi subjek. (b) Wawancara dilakukan dengan Subjek dan significant others (keluarga Subjek dan pengasuh). Wawancara bertujuan untuk mendapatkan informasi mengenai riwayat terjadinya gangguan, keseharian subjek, hambatan-hambatan yang dialami subjek, kemampuan Subjek dalma rawat diri dan mengidentifikasi halusinasi, waham atau delusi pada diri subjek. (c) Penggunaan test psikologi menggunakan test grafis (BAUM, HTP, DAP), Wartegg untuk melihat kepribadian Subjek secara lebih mendalam. (d) TAT digunakan untuk melihat kebutuhan atau tekanan yang dialami subjek, (e) Penggunaan SSCT dan WWQ untuk melihat keterkaitan Subjek dan pandangan Subjek mengenai masa lalu. (f) WAIS digunakan untuk melihat inteligensi dan adanya kemunduran mental (MD) pada diri subjek.

\section{Presentasi Kasus}

Subjek merupakan seorang perempuan berusia 48 tahun. Subjek merupakan anak ke 2 dari 4 bersaudara. Subjek sering melamun, duduk dengan pandangan kosong dan seringkali mengomel sendiri. Subjek mengalami gangguan dengan onset sejak dirinya remaja pada usia 18 tahun. Riwayat permasalahan yang dialami Subjek muncul pada saat Subjek remaja masih duduk di bangku SMP kelas 2. Pada saat itu Subjek memiliki postur tubuh gemuk dan berkulit hitam. Hal ini menyebabkan Subjek dibully oleh teman-temannya hingga menyebabkan Subjek tertekan dan menarik diri dari lingkungan sosialnya. Subjek memiliki prestasi sekolah yang rendah selama duduk di bangku sekolah. Subjek tidak memiliki teman dekat untuk bercerita dan 
tidak menceritakan permasalahan ini kepada orang tuanya. Subjek menganggap dirinya bukan anak kandung dari orang tuanya melainkan anak tumbal. Hal ini dikarenakan Subjek menilai perlakuan orangtua terhadap saudaranya yang lain lebih baik daripada perlakuan terhadap dirinya.

Subjek juga memiliki kerentanan psikologis berupa sifat yang tertutup. Kerentanan psikologis dari Subjek dapat diperoleh dari keturunan, dimana kakek Subjek juga menderita gangguan jiwa. Hal ini menyebabkan segala permasalahan Subjek disimpan sendiri oleh Subjek kaena tidak memiliki teman dekat untuk bercerita. Subjek juga tidak dekat dengan orang tuanya. Ayah Subjek merupakan pensiunan ABRI dan ibu Subjek merupakan IRT. Ayah Subjek memiliki sifat keras dan otoriter ketika mendidik subjek. Ayahnya sering memukuli apabila Subjek berbuat salah atau mendapatkan nilai yang buruk dalam pelajarannya. Sedangkan ibu Subjek kurang dekat dengan Subjek karena sibuk mengerjakan perkerjaan rumah dan mengurus adik-adiknya. ibu Subjek kurang berperan dalam keluarga dan lebih cenderung pasif. Sehingga ibu Subjek hanya mengikuti suaminya dalam hal mendidik anak-anaknya. Subjek juga tidak begitu dekat dengan kakak perempuannya karena kakaknya memiliki teman-teman sendiri dan sering menghabiskan waktu diluar rumah. Adik-adik Subjek dengan beda usia 3 tahun juga tidak begitu dekat dengan subjek. Ketika Subjek duduk di bangku SMP adik Subjek masih berada di bangku SD dan adik bungsu Subjek masih balita. Sedangkan kakak Subjek sudah berada pada jenjang SMA.

Setelah lulus SMK Subjek dijodohkan oleh orang tuanya dengan laki-laki yang belum pernah dikenal subjek. Laki-laki tersebut dinilai tidak mencintai dan menyayangi Subjek dan akhirnya selingkuh seteah tiga tahun menikah. Kemudian Subjek dan suaminya memutuskan untuk bercerai. Hal ini menjadi pencetus gangguan yang dialami subjek. Tekanan-tekanan yang diperoleh Subjek dari masa sekolahnya, keluarga dan suami Subjek depresi. Subjek lebih menutup dirinya, mengomel dan marah tanpa adanya penyebab yang jelas, Subjek juga sering melamun dan susah tidur, bahkan Subjek pernah melakukan percobaan bunuh diri dengan cara meminum racun serangga. Selain itu juga muncul delusi bahwa semua orang sedang menatap Subjek dan membicarakan kondifi fisik Subjek yang gemuk dan berkulit hitam. Halusinasi Subjek bertipe auditori sehingga membuat Subjek tiba-tiba mendengar suara-suara yang menurutnya berisik dan akhirnya mengamuk.

Kepercayaan Subjek tersebut membuat Subjek semakin tidak percaya diri dan secara terus menerus menganggap bahwa dirinya bodoh dan jelek. Awalnya keluarga Subjek mengetahui keanehan yang muncul dari perilaku Subjek yang telanjang dan berjalan di sekeliling rumah. Kemudian keluarga membawa Subjek ke Menur, RSJ Radjiman Lawang dan ke pondok dimaksudkan agar Subjek belajar keagamaan lebih dalam sebagai upaya untuk mengobati subjek. Subjek pernah relapse beberapa kali hingga akhirnya keluarga memutuskan untuk dirawat di Yayasan Dian Atmajaya hingga saat ini.

Kondisi Subjek saat ini sering menceritakan mengenai masa lalunya dengan kata-kata yang terus berulang dan terkadang tidak nyambung. Subjek sering melamun, tertawa sendiri dan kesulitan tidur apabila tidak mengkonsumsi obat. Subjek cenderung kekanak-kanakan apabila tidak mendapatkan sesuatu yang diinginkan Subjek akan mengamuk dan menolak untuk melakukan apapun. Subjek juga sering meminta-minta makanan pada pasien lainnya. Perasaan Subjek sangat cepat berubah tanpa adanya pemicu yang jelas. Apabila sebelumnya Subjek memiliki perasaan yang baik, kemudian dalam hitungan menit perasaan tersebut berubah drastis menjadi marah uring-uringan dan mengomel sendiri. Subjek juga seringkali membicarakan bahwa dirinya tidak mampu melakukan apapun karena dirinya bodoh. Subjek menganggap dirinya bodoh dikarenakan dirinya tidak suka membaca. Subjek juga terus membawa tasnya berisi kosmetik (lipstick, bedak, kaca dan sisir). Tas tersebut selalu dibawa Subjek walaupun sedang mandi dan tidur karena Subjek merasa kurang percaya diri. Setiap beberapa menit sekali 
Subjek akan berkaca, menggunakan bedak dan lipstik kemudian membicarakan bahwa dirinya jelek, hitam dan tidak memiliki gigi dan akhirnya makeup tersebut dihapus. Setelah menghapus makeup selang waktu 10 menit kemudian Subjek akan kembali memakai makeup dan menyisir rambutnya. Perilaku tersebut merupakan perilaku sterotype yang terus diulang oleh subjek.

Hasil asesmen menggunakan WHODAS menunjukkan pada aspek pemahaman dan komunikasi secara umum Subjek mampu memahami perkataan orang dan mampu berkomunikasi dengan baik. Subjek mampu mempertahankan komunikasinya dan memahami instruksi yang diberikan. Pada aspek performance fisik Subjek kurang mampu berdiri selama 30 menit atau berkeliling. Subjek cenderung pasif pada kegiatan fisik dan lebih senang duduk mengamati. Seperti halnya ketika senam pagi Subjek menolak untuk mengikuti senam karena merasa dirinya tidak akan mampu mengikuti gerakan senam. Pada aspek perhatian akan diri Subjek memiliki kemandirian untuk mengurus diri. Subjek rajin mendi dan mengganti baju tanpa bantuan dari pengasuh. Pada aspek pastisipasi di lingkungan sosial dan menghabiskan waktu bersama orang lain menunjukkan Subjek mampu memulai dan mempertahankan percakapan. Subjek menyambut dan memulai percakapan dengan orang baru ketika Subjek merasa dirinya diperhatikan oleh orang tersebut. Subjek menyadari kondisinya dan pandangan keluarga mengenai kondsinya, selain itu Subjek mampu berkomunikasi dengan baik dan memahami konsep waktu. Namun terkadang Subjek memiliki emosi yang kurang stabil.

Subjek tidak melakukan coping untuk mengatasi permasalahan-permasalahan yang dialaminya. Hasil test WAIS Subjek memiliki inteligensi pada kategori rata-rata bawah dimana Subjek akan merasa kesuitan dalam hal akademik dan pengambilan keputusan. Hal ini menyebabkan Subjek cenderung pasif dan menghindar apabila mengalami permasalahan dikarenakan merasa kesulitan untuk memikirkan penyelesaian masalah. Dari hasil Grafis DAP terlihat bahwa Subjek mengalami kesulitan untuk mengikuti instruski dari orang lain. Instruksi dapat berupa nasehat-nasehat dari orang lain hal ini dapat dikarenakan Subjek memiliki kapasitas inteligensi yang kurang dan merasa kesulitan. Subjek juga memiliki kecenderunga impulsive, hal ini sesuai dengan perilaku Subjek dimana Subjek akan marah-marah dan mengamuk apabila dirinya tidak mendapat apa yang diinginkan. selama observasi ketika melakukan test Subjek akan mengerjakan dengan buru-buru tanpa berpikir panjang. Hal ini sesuai dengan hasil test Grafis DAP. Hasil keseluruhan test Grafis dan WWQ sifat Subjek yang paling menonjol adalah kecenderungan adanya impulsive, dependensi, memiliki emosi yang tidak stabil, dan adanya keraguan dalam diri Subjek akan kemampuannya yang juga terlihat pada hasil test SSCT pada aspek konsep diri. Hasil ini sesuai dengan perilaku Subjek sehari-hari dimana seringkali Subjek tidak percaya diri dan membutuhkan orang lain dalam kesehariannya. Subjek juga seringkali menolak untuk mengerjakan tugas atau mengikuti suatu kegiatan karena menganggap dirinya tidak mampu.

Hasil test TAT menunjukkan adanya kebutuhan akan perhatian dan menjadi sosok yang dihormati oleh orang lain. Masa lalu Subjek yang terus dibully dan tidak mendapat kasih sayang dalam keluarga mendorong Subjek memiliki kebutuhan akan penghargaan yang besar. Hasil test SSCT pada aspek heteroseks berada pada kategori adanya indikasi mengalami gangguan. Artinya Subjek merasa bahwa dirinya merupakan seseorang yang tidak disenangi dalam pergaulan terutama dengan lawan jenisnya. Kecilnya minat Subjek untuk membangun hubungan dengan lawan jenis membuat dirinya cenderung menghindari berkomunikasi dengan lawan jenis. Masa lalu Subjek yang ditinggal selingkuh masih menimbulkan efek trauma dalam diri subjek. Sedangkan pada aspek hubungan Subjek dengan keluarga terdapat indikasi adanya gangguan sikap terhadap kehidupan keluarga. Subjek memiliki pandangan yang kurang baik terhadap kehidupan keluarganya. Subjek memiliki kecenderungan bersikap acuh dan kurangnya ikatan emosional antara anggota keluarga terutama pada orang tua. Subjek juga kurang memiliki kedekatan dengan keluarganya dan kurang bersikap terbuka. Hal ini dikarenakan 
orang tua Subjek yang kurang memberikan kasih sayang dalam diri Subjek dan ayah Subjek yang bersifat otoriter.

Hambatan yang dialami Subjek menunjukkan kurangnya kepercayaan diri Subjek dimana kepercayaan diri merupakan keyakinan terhadap diri sendiri sehingga mampu mengatasi permasalahan dengan baik. Kepercayaan diri juga dapat dilihat melalui hubungan dengan orang lain, yaitu dimana individu tidak merasa inferior dan canggung apabila berhadapan dengan banyak orang (Hambly, 1997). Sedangkan individu yang memiliki kepercayaan diri yang kurang ditandai dengan (1) cenderung merasa tidak aman, (2) tidak bebas, (3) ragu-ragu, (4) membuang waktu dalam mengambil keputusan, (5) perasaan rendah diri, (6) cenderung menyalahkan lingkungan sebagai penyebab apabila mengalami suatu permasalahan (Anthony, 2004). Ciri-ciri kurangnya kepercayaan diri tersebut sesuai dengan kondisi Subjek dimana Subjek merasa rendah diri, menyalahkan lingkungan, tidak mampu mengambil keputusan, dan pasif dalam suatu kegiatan.

Aspek kepercayaan diri menurut Lauster (1978), diantaranya (a) kemampuan akan kepercayaan diri. Pada aspek ini Subjek memiliki keyakinan akan kemampuan diri yang rendah. Subjek percaya bahwa dirinya tidak memiliki kemampuan dan bodoh (b) optimis, Subjek memiliki optimism yang kurang, dimana dirinya kurang memiliki harapan akan masa depan dan cenderung terpaku pada masa lalu. (c) Objektif, Subjek kurang mampu melihat segala sesuatu secara keseluruhan dan lebih mengutamakan emosi. (d) bertanggung jawab, Subjek kurang memiliki tanggung jawab akan tugas-tugasnya dan cenderung menghindari tanggung jawab yang diberikan. (e) rasional dan realistis, Subjek kurang berpikiran logis dalam menghadapi segala hal. Subjek lebih memandang segala sesuatu dengan emosional dan menghubungkan dengan masa lalunya. Secara umum dari kelima aspek tersebut, Subjek memiliki kepercayaan diri yang kurang (Indrawati, Irmawati, \& Lestari, 2018).

Riwayat terbentuknya gangguan Subjek dapat dijelaskan menggunakan teori Diathesis stress. Dimana hingga terbentuknya gejala-gejala terdapat kontribusi dari faktor biologis, psikologis meliputi stress dan tekanan dan faktor sosial individu (Havelka, Despot, \& Lu, 2015). Subjek memiliki faktor genetis akan kerentanan psikologis untuk mengalami gangguan jiwa dari kakeknya. Sedangkan Subjek memiliki tekanan-tekanan yang ada dalam dirinya tanpa adanya coping yang baik. Sehingga tekanan tersebut menyebabkan Subjek mengalami stress dan depresi hingga akhirnya menimbulkan gejala-gejala skizofrenia. Kemudian lingkungan sosial Subjek yang merupakan salah satu sumber tekanan Subjek juga berkontribusi menyebabkan gangguan yang dialami subjek. Subjek tidak memiliki teman dekat mauapun kedekatan dengan keluarga.

Permasalahan kurangnya kepercayaan diri yang dialami Subjek dapat dijelaskan menggunakan teori behavior. Teori ini berfokus pada masa depan dalam hal penyelesaian masalah yang dialami Subjek. Teori ini memandang bahwa perilaku merupakan respon dari stimulus yang diperoleh individu (Davis, Campbell, Hildon, Hobbs, \& Michie, 2015). Teori behavior memandang kepribadian individu pada hakikatnya merupakan suatu perilaku. Perilaku dibentuk berdasarkan pengalaman individu yang dapat berupa interaksi individu dengan lingkungannya (Samuel, Commodore-mensah, \& Himmelfarb, 2014). Hal tersebut dapat membentuk karakter dari manusia hingga menciptakan manusia sebagai sosok yang unik dan berbeda satu sama lain. Manusia masing-masing memiliki pengalaman yang berbeda-beda. Sehingga kepribadian individu merupakan cerminan dari pengalaman individu atau dapat diartikan sebagai stimulus yang diterimanya. Menurut pandangan teori Behavior individu yang mengalami hambatan atau gangguan dikarenakan adanya perilaku yang maladaptive sebagai bentuk adanya hambatan interaksi individu dengan lingkungannya (Brewer \& Rimer, 2008).

Teori ini sesuai dengan Subjek dimana terdapat proses pembelajaran dari lingkungan hingga terbentuk perilaku negatif seperti menarik diri dari lingkungannya. Subjek memiliki pengalaman buruk ketika berinteraksi dengan lingkungannya yaitu ketika teman-temanya membullynya dan 
ketika ayahnya memarahinya ketika nilai akademiknya buruk. Subjek tidak memiliki kekuatan untuk membela diri atau coping untuk mengatasi permasalahan. Hal ini membentuk skema dalam kognitif Subjek bahwa dirinya merupakan orang yang jelek, gendut, bodoh dan tidak dapat melakukan apapun. Pada akhirnya Subjek berperilaku pasif, tidak percaya diri, menarik diri dari lingkungan sosialnya, menghindari segala tugas dan kegiatan, dan membawa tas makup kemanapun dia pergi karena merasa tidak percaya diri dengan penampilannya .

\section{Diagnosis dan Prognosis}

\section{Diagnosis}

Berdasarkan uraian kasus, hasil asesmen dan rujukan yang ada di Diagnostic and Statistical Manual of Mental Disorder Fifth Edition (DSM-V), maka dapat ditegakan diagnosa bahwa Subjek memenuhi kriteria 295.90 (F20.9) Skizofrenia, dengan permasalahan kurangnya kepercayaan diri terutama dalam hal kemampuan yang dimiliki.

\section{Prognosis}

Prognosis perkiraan keberhasilan Subjek untuk melakukan intervensi hingga akhir adalah buruk. Hal ini dikarenakan gangguan yang dialami Subjek memiliki onset yang lama, sehingga gejala gangguan seperti halusinasi dan emosi tidak stabil seringkali muncul. Subjek memiliki kapasitas inteligensi rata-rata bawah. Subjek mudah menyerah pada soal atau kegiatan rumit dan membutuhkan dukungan yang besar dari lingkungannya.

\section{Intervensi}

Intervensi menggunakan teknik positive activity penggunaan teknik ini menggunakan prinsip-prinsip behavioral yaitu belajar sosial. Dengan memberikan aktivitas-aktivitas yang menghasilkan suatu kerajinan atau benda-benda secara konkrit Subjek belajar bahwa dirinya memiliki kemampuan. Terapi positive activity secara keseluruhan memberikan kesempatan Subjek untuk mengeksplore kekuatan-kekuatan atau kemampuan Subjek ketika melihat dirinya mampu melakukan sesuatu, secara perlahan Subjek akan mempercayai bahwa dirinya memiliki kemampuan (Shin \& Lyubomirsky, 2016). Kepercayaan Subjek akan kemampuannya yang terbangun secara perlahan akan membentuk kepercayaan diri dalam diri Subjek (Sxufkdvh et al., 2014).

Intervensi yang digunakan juga berfokus untuk meningkatkan kepercayaan diri (self confident) pada diri subjek. Menunjukkan bahwa sebenarnya Subjek memiliki kemampuan untuk melakukan sesuatu. Intervensi menggunakan positive activity dengan pedekatan behavior. Hal ini dikarenakan pendekatan behavior lebih cocok karena tidak terlalu menonjolkan kognisi melainkan lebih berfokus pada perilaku. Positif activity diberikan dengan cara melakukan kegiatan-kegiatan positif dan sederhana seperti membuat lukisan, merangkai manik-manik hingga menjadi speerti perhiasan, dsb. Efek terapeutik pada intervensi ini adalah dengan memeberikan reward verbal ketika Subjek mau melakukan kegiatan dan berhasil menyelesaikan tugas.

Target intervensi positive activity adalah untuk meningkatkan kepercayaan dalam diri subjek. Permasalahan Subjek mengenai rendahnya kepercayaan diri menghambat fungsi sosialnya dan performa Subjek dalam melakukan kegiatan. Kepercayaan diri merupakan hal penting untuk mendorong Subjek agar dirinya mampu memaksimalkan kemampuannya dalam mengikuti suatu kegiatan maupun berinteraksi. Rendahnya kepercayaan diri Subjek menyebabkan Subjek menarik diri dan menghindari kegiatan-kegiatan. Penggunaan positive activity untuk meningkatkan kepercayaan diri Subjek juga bertujuan untuk memudahkan Subjek pasca keluar dari perawatan untuk melakukan suatu pekerjaan dan berinteraksi. 
Penerapan positive activity dilakukan sebanyak 8 kali pertemuan ( 8 hari) dengan tiga tahap dengan total 14 sesi. Setiap pertemuan dapat dilakukan sebanyak 2 sesi dengan waktu 30-60 menit. Berikut ini tahapan intervensi yang dilakukan:

1. Pengenalan terapi dan mengidentifikasi kegiatan yang akan dilakukan selama proses terapi. Dimulai dengan membangun rapor (perkenalan), selain itu pada tahap ini juga terdapat penjelasan mengenai terapi, prosedur terapi, tujuan dari terapi dan diakhiri dengan kontrak terapi.

2. Membangun komitmen. Setelah Subjek memahami mengenai terapi yang akan dilakukan kemudian mengidentifikasi keinginan atau minat Subjek untuk melakukan kegiatan selama terapi.

3. Implementasi program 1 membuat perhiasan dari manik-manik. Terapis meminta Subjek untuk membuat perhiasan dari manik-manik yang telah disiapkan. Target Subjek harus mampu membuat 1 gelang dan 1 kalung.

4. Evaluasi dan feedback

5. Implementasi program 2 melihat video mengenai indivdu yang memiliki kekurangan fisik. Terapis meminta Subjek untuk melihat video lalu memberikan komentar mengenai video tersebut. Kemudian memberikan motivasi agar Subjek mampu menerima kekurangannya yang seringkali disebutkan.

\section{Bermain UNO STACKO}

7. Melipat kertas origami dengan bentuk kepala kelinci. Subjek mampu melipat sebanyak 5 kertas dengan arahan terapi. Subjek melakukan kegiatan ini bersama orang lain agar Subjek mulai terbiasa melakukan kegiatan bersama orang lain.

8. Evaluasi dan feedback.

9. Mewarnai lukisan di kanvas. Terapis meminta Subjek untuk mewarnai lukisan yang kemudian di pajang sebagai bukti konkrit apabila Subjek mampu melakukan suatu hal.

10. Evaluasi dan feedback.

11. Bermakeup. Subjek diminta untuk merias wajah orang lain Subjek memahami bahwa dirinya memiliki kemampuan untuk membantu orang lain. Hal ini mempertimbangkan minat Subjek yang tinggi terhadap makeup.

12. Evaluasi dan feedback.

13. Terminasi dan mencegah relapse. Pemberian feedback tentang kinerjanya selama implementasi program, mengakhiri program dan memastikan Subjek berkomitmen menerapkan program dalam kehidupan sehari-hari terlepas dari intervensi.

14. Follow Up hasil dari sesi ini adalah kepercayaan diri Subjek mulai terbentuk denga baik, Subjek mulai mengikuti kegiatan senam pagi dan intensi menganggap dirinya jelek dan bodoh muai berkurang. 


\section{Hasil dan Pembahasan}

\section{Hasil}

Hasil intervensi Subjek menunjukkan dari 14 sesi Subjek mampu memenuhi taget sebanyak 11 sesi sedangkan terdapat 4 target yang tidak terpenuhi. Target yang tidak terpenuhi oleh Subjek diantaranya bermain UNO STACKO, melipat kertas origami, dan mewarnai lukisan. Terdapat dua kali percobaan pada sesi bermain UNO STACKO dimana Subjek ditargetkan untuk bermain lebih dari 15 menit Subjek menolak untuk mengikuti pada percobaan pertama. Sedangkan pada percobaan kedua setelah melakukan pendekatan personal akhirnya Subjek mau untuk mengikuti permainan dan berhasil bermain lebih dari 15 menit. Pada sesi melipat kertas origami Subjek gagal pada kedua kali percobaan dan menolak untuk ikut melipat lalu menghindar. Kemudian pada sesi mewarnai lukisan di kanvas Subjek gagal pada percobaan pertama. Subjek menghindar dan pergi ke kamarnya. Setelah dilakukan pendekatan personal, diberikan dorongan motivasi pada percobaan kedua Subjek akhirnya mampu menyelesaikan satu lukisan untuk kemudian dipajang. Secara umum Subjek membutuhkan dorongan yang besar untuk melakukan suatu tugas atau mengikuti kegiatan hingga pada akhirnya Subjek meyakini bahwa sebenarnya dirinya memiliki kemampuan. Subjek juga kurang mempercayai dirinya untuk menyelesaikan tugas yang rumit seperti melipat origami menjadi bentuk kepala klinci.

Kepercayaan diri Subjek pasca intervensi dievaluasi menggunakan Self Confident Scale yang digunakan pretest dan posttest. Hasil perbandingan pretest dengan posttest dapat dilihat pada Gambar 1.

Terdapat peningkatan pada posttest mengenai pemahaman Subjek akan kepercayaan dirinya. Pasca intervensi Subjek mulai memahami bahwa dirinya memiliki kemampuan yang dapat digunakan untuk membantu orang lain seperti bermakeup. Kemajuan yang dialami Subjek diantaranya Subjek mulai mengikuti senam pagi walaupun belum sampai akhir senam yang sebelumnya Subjek hanya duduk melihat orang lain senam. Obrolan-obrolan Subjek mengenai kekurangannya yang selalu dikatakan sudah mulai berkurang. Subjek mulai mengatakan apabila dirinya bersyukur setelah melihat video mengenai orang yang memiliki kondisi fisik kurang sempurna. Subjek mulai mau menggunakan make-up terutama lipstick yang sebelumnya kurang percaya diri menggunakan lipstick dikarenakan ompong. Sehingga setelah menggunakan lipstick Subjek akan berkaca lalu menghapus lipsticknya. Perubahan perilaku setelah intervensi dapat dilihat melalui Tabel 1.

Tabel 1. Perubahan perilaku sebelum dan setelah intervensi

\begin{tabular}{lll}
\hline Sebelum & Sesudah \\
\hline $\begin{array}{l}\text { Tidak mau mengikuti senam pagi } \\
\text { atau kegiatan lainnya }\end{array}$ & $\begin{array}{l}\text { Subjek mulai mengikuti senam pagi walaupun } \\
\text { belum sampai senam selesai dan mulai berani } \\
\text { mencoba mengikuti kegiatan-kegiatan dan } \\
\text { mengerjakan tugas yang diberikan. }\end{array}$ \\
$\begin{array}{l}\text { Murung dan membicarakan bahwa } \\
\text { dirinya jelek, gendut, ompong dan } \\
\text { bodoh }\end{array}$ & terganti dengan kalimat-kalimat bahwa dirinya \\
& bersyukur memiliki keadaan fisik yang lengkap \\
& dan menyadari bahwasannya semua wanita \\
& cantik dan setiap manusia memiliki kemampuan \\
& asalkan berani mencoba. Sehingga intensitas \\
& perkataan yang menyebabkan dirinya insecure \\
& mulai berkurang. \\
\hline
\end{tabular}




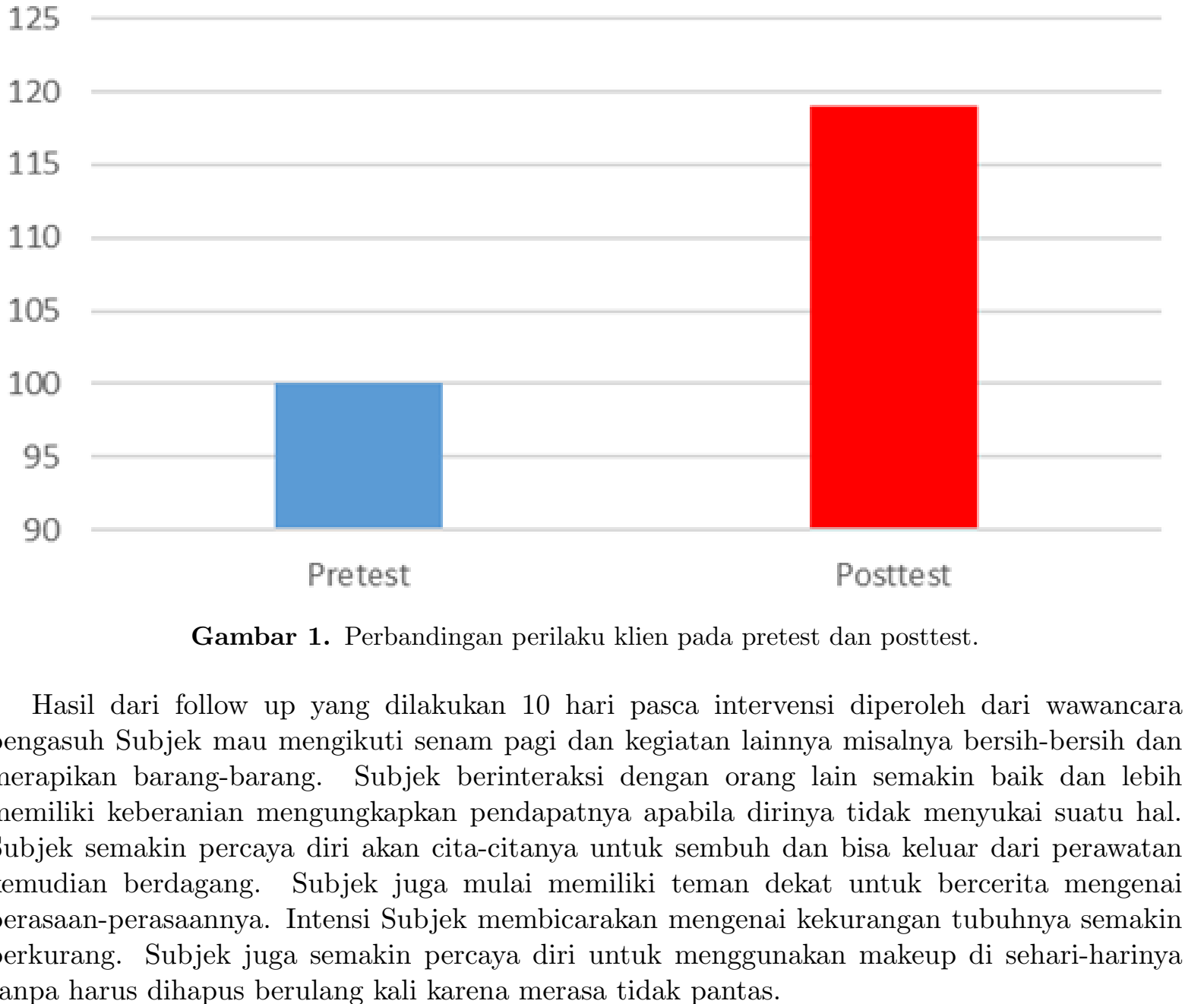

\section{Pembahasan}

Aktivitas yang dilakukan dalam penggunaan intervensi positive activity telah disesuaikan dengan minat dan kemampuan subjek. Pada beberapa kegiatan Subjek membutuhkan dorongan yang cukup besar dari orang lain. Seperti ketika melakukan kegiatan yang rumit yaitu melipat kertas origami Subjek merasa kesulitan dan menghindari. Membutuhkan waktu kurang lebih 2 jam untuk memberikan Subjek motivasi atau dorongan agar dirinya mau untuk kembali mencoba. Subjek berhasil menyelesaikan dua kertas dengan waktu yang cukup lama dan memerlukan bantuan orang lain. Kesulitan Subjek untuk menyelesaikan pekerjaan rumit dapat dikarenakan inteligensi Subjek yang berada pada tahap rata-rata bawah. Artinya Subjek mampu menyelesaikan suatu tugas atau instruksi namun membutuhkan waktu yang lama untuk melakukannya. Hal ini juga menunjukkan adanya dependensi dalam diri subjek, dimana Subjek membutuhkan dorongan dari orang lain untuk menyelesaiakn tugas maupun melakukan kegiatan.

Pemberian intervensi positive activity pada Subjek dimaksudkan agar kepercayaan diri Subjek mulai terbentuk. Selama Subjek melakukan berbagai aktivitas dalam terapi selalu diberikan reward verbal oleh terapis maupun orang lain. Dengan diberikan reward verbal oleh teman-temannya, secara perlahan Subjek akan mempelajari bahwa di lingkungan sosialnya dirinya tidak dianggap sebagai individu yang tidak memiliki kemampuan dan memiliki bentuk fisik yang tidak menarik seperti yang selama ini dipercayai subjek. Kepercayaan Subjek apabila dirinya bodoh karena tidak kuliah dan jelek karena memiliki postur tubuh gemuk, berkulit 
hitam dan ompong juga mempengaruhi rendahnya kepercayaan diri subjek. Oleh karena itu, dalam intervesi Subjek diminta untuk melihat video mengenai individu yang memiliki kondisi fisik kurang normal namun memiliki kepercayaan diri yang baik. Pada proses berfungsi untuk menumbuhkan kepercayaan diri Subjek melalui video motivasi. Terapis memberikan dorongan dan penjelasan kepada Subjek utnuk percaya diri akan kondisinya karena banyak orang lain yang mampu percaya diri walaupun dengan keterbatasan fisik. Kemajuan Subjek setelah melakukan sesi tersebut adalah intensi Subjek membicarakan kekurangan fisiknya mulai berkurang dan kalimat-kalimat tersebut dirubah dengan kalimat yang menunjukkan kebersyukuran.

Video motivasi yang dilihat Subjek mampu mengalihkan perasaan negatif Subjek hingga akhirnya Subjek lebih berfokus untuk mengingat orang-orang yang berada dalam video. Penggunaan positive activity dengan pendekatan behavior dinilai sesuai dengan kamapuan individu yang memiliki kapasitas inteligensi rata-rata bawah. Penggunaan pendekatan behavior lebih praktis untuk mengubah perilaku Subjek (Armitage \& Conner, 2001). Perilaku Subjek yang sebelumnya pasif hingga mulai berani mengikuti kegiatan-kegiatan dengan pemberian motivasi dan reward verbal. Hasil dari positive activity diantaranya lukisan, perhiasan juga dapat sebagai bukti konkrit bahwasannya Subjek mampu melakukan suatu hal. Dengan demikian, apabila perasaan negative mengenai ketidak berdayaan mulai muncul Subjek disarankan untuk melakukan self talk yang sebelumnya diajarkan dan melihat benda-benda yang berhasil diselesaikan. Penggunaan self talk dan melihat benda-benda yang berhasil diselesaikannya walaupun sebelumnya terjadi penolakan juga menjadi salah satu upaya untuk mencegah relapse.

Perubahan perilaku Subjek selama intervensi dapat dilihat ketika senam pagi dan intensi Subjek menyatakan bahwa dirinya jelek dan bodoh mulai berkurang. Sebelum dilakan intervensi Subjek lebih memilih diam dan pasif dalam setiap kegiatan secara perlahan Subjek mulai mengikuti senam walaupun belum sampai selesai. Berdasarkan hasil pretest dan posttest pemahaman Subjek mengenai kepercayaan dirinya juga meningkat setelah diberikan intervensi. Individu di lingkungan subek juga dihimbau untuk terus memberikan dukungan kepada Subjek untuk melakukan kegiatan-kegiatan. social support yang diberikan kepada Subjek dapat menjadi upaya mencegah relapse dan memperkuat kepercayaan diri Subjek (Havassy, Hall, \& Wasserman, 1991).

Pada kasus Subjek dimana Subjek mengalami permasalahan kurangnya kepercayaan diri teridentifikasi permasalahan lain yang dialami Subjek yaitu kurangnya harga diri. Namun pada kasus ini difokuskan pada kurangnya kepercayaan diri Subjek. Hal tersebut dikarenakan permasalahan kurangnya kepercayaan diri dianggap lebih urgent dan lebih observable untuk ditangani. Harga diri merupakan penilaian yang dilakukan oleh individu terhadap dirinya sendiri. Penilaian yang diberikan oleh dirinya biasanya menunjukkan penerimaan atau penolakan terhadap dirinya dan menunjukkan seberapa jauh kepercayaan dirinya akan berhasil, merasa penting dan berharga (Orth \& Robins, 2014). Harga diri memiliki fungsi subjektif dimana hanya individu tersebut yang mengetahui seberapa besar dirinya mampu menilai dan menghargai dirinya. Namun, pada kasus Subjek dimana Subjek menghindari melakukan kegiatan, membawa tas makeup dan membanding-bandingkan dirinya dengan orang lain menunjukkan bahwa Subjek memenuhi ciri-ciri kurangnya kepercayaan diri. Sesuai dengan penelitian yang dilakukan oleh (D'Mello, Monteiro, \& Pinto, 2018) menunjukkan terdapat hubungan positif antara kepercayaan diri dengan harga diri. Artinya apabila terdapat peningkatan kepercayaan diri maka secara tidak langsung harga diri individu juga meningkat. Namun, sebagai rekomendasi pada penanganan kasus selanjutnya akan lebih maksimal apabila terdapat intervensi tersendiri untuk meningkatkan harga diri Subjek. 


\section{Simpulan}

Positive activity didesain dengan adanya kegiatan melihat video motivasi mampu untuk meningkatkan kepercayaan diri Subjek. Dengan memberikan reward verbal setiap Subjek mau melakukan kegiatan dan menyelesaikan tugas mampu memotivasi Subjek dalam melakukan kegiatan. Pemahamn Subjek juga mulai bertambah mengenai kepercayaan dirinya. Adanya Social Support dan melihat hasil dari terapi (gelang dan lukisan) ketika perasaan negatif Subjek mulai muncul merupakan upaya untuk mencegah relapse. Peran orang lain untuk memberikan motivasi menjadi sangat penting bagi diri subjek. Hal ini dapat disebabkan adanya dependensi dalam diri Subjek. Subjek memiliki hambatan untuk melakukan tugas atau mengikuti instruksi untuk mengikuti tugas yang rumit. Sehingga seringkali Subjek menghindar dan menolak untuk mengerjakan tugas atau mengikuti kegiatan. Hal ini dapat dikarenakan rendahnya motivasi dalam diri Subjek.

\section{Referensi}

Anthony, R. (2004). Ultimate Secrets of Total Self Confidence. USA: Pinguin Publishing Group.

Armitage, C. J., \& Conner, M. (2001). Efficacy of the Theory of Planned Behaviour: A meta-analytic review. Social Psychology, 40(1), 471-499.

Brewer, N. T., \& Rimer, B. K. (2008). Perspectives on Health Behavior Theories That Focus on Individuals. Health Behavior and Health Education: Theory, Research and Practice.

Chan, R. C. K., Ph, D., Wong, J. O. Y., Bergmann, A., Falkai, P., Pomarol-clotet, E., .. Ph, D. (2006). Clozapine Alone versus Clozapine and Risperidone with Refractory Schizophrenia. The New England Journal of Medicine, 354, 472-482.

D'Mello, L., Monteiro, M., \& Pinto, N. (2018). A Study on the Self Esteem and Academic Performance among the Students. Internaational Journal of Health Sciences and Phaarmacy, 2(1), 1-7.

Davis, R., Campbell, R., Hildon, Z., Hobbs, L., \& Michie, S. (2015). Theories of Behaviour and Behaviour Change across the Social and Behavioural Sciences: a Scoping Review. Health Psychology Review, 9(3), 323-344. Retrieved from http://dx.doi.org/10.1080/17437199.2014.941722

Hambly, K. (1997). Psikologi Populer: Bagaimana Meningkatkan Rasa Percaya Diri (Terjemahan FX Budianto). Jakarta: Arcan.

Harvey, P. D., \& Penn, D. (2010). Update on Cognition Social Cognition: in People with Schizophrenia? Psychiatry, 7(2), 41-44.

Havassy, B. E., Hall, S. M., \& Wasserman, D. A. (1991). Social Support and Relapse: Commonalities among Alcoholics, Opiate Users, and Cigarette Smokers. Addictive Behavior, 16(1), 235-246.

Havelka, M., Despot, J., \& Lu, D. (2015). Biopsychosocial Model - The Integrated Approach to Health and Disease. Health Psychology, 33(1), 303-10.

Indrawati, E., Irmawati, D. J., \& Lestari, D. D. (2018). Improving Self Confidence of Adolesence through Counseling Directive, 7(5), 373-375. https://doi.org/10.21275/ART20182003

Lyubomirsky, S., \& Layous, K. (2013). How do Simple Positive Activity Increase Well Being? Psychological Science, 22(1), 57-62.

Mcgirr, A., \& Turecki, G. (2008). What is specific to suicide in schizophrenia disorder? Demographic, clinical and behavioural dimensions. Schizophrenia Research, 98(1), 217-224. https://doi.org/10.1016/j.schres.2007.09.009

Orth, U., \& Robins, R. W. (2014). The Development of Self-Esteem. Current Directions in Psychological Science, 23(5), 381-387.

Ritsner, M., Ponizovsky, A., Timinsky, I., Bistrov, E., \& Modai, I. (2003). Quality of Life and Coping with Schizophrenia Symtoms. Quality of Life R, 12, 1-9.

Rosenheck, R. A., Perkins, D. O., Keefe, R. S. E., Ph, D., Davis, S. M., Davis, C. E., .. Severe, J. (2005). Effectiveness Antipsychotic Drugs in Patients with Chronic Schizophrenia. The New England Journal of Medicine, 353(12), 1209-1223.

Samuel, L. J., Commodore-mensah, Y., \& Himmelfarb, C. R. D. (2014). Developing Behavioral Theory With the Systematic Integration of Community Social Capital Concepts. Health Education \& Behavior, 41(4), 359-375.

Shin, L. J., \& Lyubomirsky, S. (2016). Positive Activity Interventions for Mental Health Conditions Basic Research and Clinical Applications.

Sxufkdvh, L., Kdv, G., Dq, E., Ri, D., Lqwhuhvw, U., Vhyhudo, I. R. U., \& Lq, G. (2014). Self Confident and the Ability to Influence, 18(2), 169-180. 
Taipale, H., Mehtälä, J., Tanskanen, A., \& Tiihonen, J. (2018). Comparative Effectiveness of Antipsychotic Drugs for Rehospitalization in Schizophrenia - A Nationwide Study With 20-Year Follow-up. Schizophrenia Bulletin, 1-7. https://doi.org/10.1093/schbul/sbx176 